\title{
Chapter 4 \\ The Coproduction of National Models of Integration: A View from France and the Netherlands
}

\author{
Christophe Bertossi, Jan Willem Duyvendak, and Peter Scholten
}

\subsection{Introduction}

The notion of national models of integration is a very popular one in comparative migration studies. These models, inspired by a historical-institutionalist perspective, are perceived as nationally and historically rooted ways of framing immigrant integration (Brubaker 1992). According to such models, how integration is defined and acted upon differs primarily according to specific national histories, differences in national identity and different views of the role of the state. A key trait of such national models is that they assume policies to be formulated and coordinated in a strongly state-centred way, reflecting national institutional legacies, national politics and public perceptions of national identity (Brubaker 1992; Koopmans and Statham 2000). In this respect, the literature distinguishes for instance the French republican model, the British race-relations model and the Dutch multicultural model.

This 'models-thinking' has had great resonance in migration studies. A key reference is Brubaker's work that juxtaposes the German and French models of citizenship upon which the foundations for integration policies in these countries were built; a differentialist approach in Germany and an assimilationist approach in France (1992). As a true historical institutionalist, Brubaker shows how the historical conditions in both countries led to the construction of these national models: a strongly developed cultural and apolitical sense of national belonging in Germany

\footnotetext{
C. Bertossi

Centre for Migration and Citizenship, French Institute for International Relations, Paris, France

J.W. Duyvendak

University of Amsterdam, Amsterdam, Netherlands

P. Scholten $(\bowtie)$

Department of Public Administration, Erasmus University Rotterdam, P.O. Box 1738, 3000 DR

Rotterdam, Netherlands

e-mail: p.w.a.scholten@fsw.eur.nl
} 
versus the state-centric tradition of nation building in France. Likewise, the work of Christian Joppke takes national models as a starting-point for comparative studies of immigrant integration (1999), as does Patrick Ireland, whose comparative study of France and Switzerland finds that national institutional conditions provide the best explanation for the type of policies that are developed (Ireland 1994). Similarly, Ruud Koopmans' Dutch-German comparison takes the differences in national models as the main explanation for the differences in effectiveness of the Dutch and German approaches (Koopmans 2007).

This chapter offers a critical discussion of the idea of national models of integration, as a characteristic of an important part of knowledge production in migration research. Our analysis focuses on the Dutch and French cases. These two countries represent two of the most pertinent cases where discourses on two very different national models have been particularly strong. In particular, we will position the alleged national models of integration in the broader academic and policy discourses of the two countries, and subsequently discuss the role that research-policy relations have played in (co-) producing these models. Rather than the models deriving their strength from either academic or policy discourse, it seems that especially the interaction between research and policy played a key role in 'coproducing' national models of integration. Thus, this chapter will reveal the opportunities as well as the great difficulties for research-policy dialogues to critically discuss national models of integration.

\subsection{National Models and Comparative Migration Research}

A national model of integration and citizenship is usually defined as a public philosophy (Schain 2009), a policy paradigm (Favell 1998; Guiraudon 1997), an institutional and discursive opportunity structure (Koopmans et al. 2005) or a national cultural idiom (Brubaker 1992). All these concepts attempt to show how social reality is structured by pre-existing ideas about a nation's self-understanding, and how such ideas frame social interactions, institutional arrangements, policy outcomes and social movements (Bertossi and Duyvendak 2012).

\subsubsection{National Models of Integration: A Critical Assessment}

What notions of politics are implied in 'national modelling'? First of all, it implies that policies are primarily oriented to the nation. Bommes and Thränhardt (2010) argue that these paradigms are national "not just because of their context dependency and insufficient clarifications on the conditions of generalisability. They are national because the modes of presenting and questions are politically constituted by the nation states for which migration becomes a problem or a challenge' (ibid: 10). Similarly, Favell (2003) shows that national models of integration are often the 
product of the 'exclusively internal national political dynamics' or 'self-sufficiency' of debates on immigrant integration in politics as well as in migration research. Thus, the development of these national paradigms must be considered a consequence of the centricity of the nation state in policy and academic discourses, rather than as accurate representations of the uniquely national character of immigrant integration policies. In fact, as Bommes and Thränhardt (2010) argue, national paradigms have distorted international comparative research (see also Bommes and Morawska 2005), often leading to what Favell (2003) describes as 'self-justificatory discourse' (see for instance the role that French-American antagonism played in the justification of the French republican 'model': Fassin 1999). Researchers have shared in this 'methodological nationalism' instead of questioning the 'national' in 'national models'.

Secondly, this perspective of models of integration emphasises that agency and collective interests are marginal dimensions in institutional arrangements and in the structure of public debates (Brubaker 1992: 13-16). Instead, normative and idealistic 'structures', 'idioms' or 'paradigms' are seen as being the primary driving force behind policies and practices related to identity, citizenship, immigration, religious diversity, and so on. Social actors, from politicians to veiled Muslim women, are portrayed as simply inheriting these ideas, using and adapting to them. In turn, a public speech on immigrants or a woman's decision to wear the hijab are also brought down to a single cause, namely the power of French republicanism or British and Dutch multiculturalism to drive individual behaviours, social movements, institutional arrangements, and policies (Koopmans et al. 2005).

Finally, models also tend to oversimplify policies and overemphasise the alleged coherency and consistency of these policies (see Bertossi and Duyvendak 2012). Policy practices tend to be far more resilient and diverse than most policy models would suggest. For instance, in Dutch as well as in French literature there have been many references to differences between how policies are formulated at the national level and how they are put into practice often at the local level. Some even speak of the decoupling of national and local policies in this respect (Favell 1998; De Zwart 2005; Poppelaars and Scholten 2008). In fact, even when policymakers claim to operate according to a specific policy model, their reasons for doing so may be based more on pragmatism and flexibility than on support for the policy model itself in its ideal-typical form. For instance, the reason why some politicians in the 1980s framed immigrant integration in terms of the multicultural model may have much more to do with their fear of anti-immigrant parties playing the race card than with their so-called multicultural policy beliefs (Scholten 2011).

On the one hand, national models seem to offer considerable advantages for comparative research on the incorporation of immigrants and their offspring into Western European countries. For one, it helps to identify striking differences among countries that have implemented different policies and adopted contradictory public conceptions of citizenship. Within this perspective, republican and assimilationist France appears to be a powerful illustration of what multiculturalism is not while in countries such as Britain and the Netherlands multiculturalism remains something undoubtedly un-French. This simplifies the otherwise highly complex and contested 
matter of immigrant integration. Models help to construct international comparative studies to assess processes of convergence or divergence between various European countries. Furthermore, by comparing ideal-typical models with specific periods, modelling can generate a better understanding of the dynamics of migrant integration policies in a country's history.

On the other hand, the danger of modelling is that the models are not only taken as tools for international comparison or for understanding historical periods. When a model begins to shape our understanding and beliefs about policies, the model becomes more than just a model: the model is then taken as an accurate historical reconstruction of policy rather than as a model of it. Models then take the place of historical analysis. In social science literature, this has often led to instances where a model is 'blamed' for the success or failure of a specific policy approach. For instance, various authors have blamed the Dutch multicultural model for the alleged failure of immigrant integration in the Netherlands (Koopmans 2007; Sniderman and Hagendoorn 2007).

\subsubsection{Migration Research and the Coproduction of Models}

Models can be very powerful as a form of 'discourse' (Hajer 1995), not just in politics and policymaking but in public debate, civil society and academia as well. Hajer speaks in this context of the formation of 'discourse coalitions,' which involve actors that are held together by a shared discourse and not necessarily by coordinated interaction. This can include various types of actors, including politicians and policymakers, as well as academics, experts, interest groups, journalists, and so on.

National models tend to be coproduced by this range of actors within such discourse coalitions (see also Scholten 2009; Duyvendak and Scholten 2011). In fact, it is the coproduction of a national model by different types of actors that can lend it significant discursive strength. For instance, the mere involvement of leading academics or reputable research institutes can provide significant authority to a discourse coalition. Furthermore, once a discourse coalition emerges and is supported by a sufficiently large or strong group of actors, a discourse can prove difficult to change. Challenging a discourse means also challenging the beliefs and interests of the groups involved in the discourse coalition. Furthermore, discourses tend to become taken-for-granted: even members of a discourse coalition may be unaware of their tacit beliefs and the presence of alternative beliefs.

This is why, according to Rein and Schön (1994), situations that are characterised by a multiplicity of coexisting discourses (or 'frames') tend to evolve in 'intractable policy controversies'. Such intractable controversies do not just involve mere disagreements about how to resolve a given problem, but fundamental differences in the naming and framing of a problem. Such controversies cannot be resolved by merely studying 'the facts', as discourse coalitions will have very different ways of selecting and interpreting these facts. Hence, intractable controversies would only be resolvable by reflecting on the deeper conceptual and normative premises that 
underlie a specific discourse (which Rein and Schön describe as 'frame reflection'). This means that actors firstly have to become aware of their own models or 'frames', secondly have to be able to put themselves in the shoes of actors with other frames, and thirdly have to be willing to adapt their discourse when required.

Recognising that researchers can and often do play a key role in such discourse coalitions also means recognising that the notion of models used by scholars is heteronomous: academic discussions about models are pervaded by normative, political and moral interests, which stem from ideological debates in the public arena in which scholars also take part (Bowen 2007; Scholten 2009; Bertossi and Duyvendak 2012). The problem here is that scholarly notions of integration models reflect and are influenced by public debates, which in turn are structured by the frames of the dominant elite, which includes influential scholars (see Scholten 2011). As a result, scholarly writings that are presented as analysing social and political phenomena can be normative as well.

This normative dimension is strikingly obvious in the literature that has addressed the issue of a possible 'crisis' of national models of integration in Europe since the beginning of the 2000s (Vertovec and Wessendorf 2009). Research on the integration of immigrants in Europe has turned into a discussion about the success or failure of traditional integration policies on the one hand, and on the other on the legitimacy of claims made by ethnic minorities, particularly when these claims are made by Muslims (Koopmans and Statham 2000). These debates have by the same token reinforced questions about Muslims' loyalty and incorporation ('are they with us or against us?') and the relevance of a category (Muslims) that is used in and is the subject of political debates.

\section{3 'The Dutch Multicultural Model'}

\subsubsection{The Invention of the Dutch Multicultural Model}

For a long time the Dutch case has been taken as one of the strongholds of a multicultural model of migrant integration. The Dutch multicultural model provided one of the first examples of a European country to adopt a multiculturalist approach to migrant integration. However, the so-called Dutch multicultural model has become subject of fierce controversy, in politics as well as in academia. In politics, some claim that the Dutch have said goodbye to the multicultural model foregood, as the Netherlands was also one of the first European countries to experience the 'assimilationist turn' in integration policies. Others contend that the model continues to inform policy practice until today. In academia, the proclaimed 'fall' 'of multiculturalism in policies and politics has also led to criticism regarding the role of social scientists in the Netherlands that had taken a key position in the development of this model. At the same time, others contend that the Dutch case has never really been characterised by a clear national multicultural model, and that in a comparative perspective, the Dutch case has many characteristics in common with other European countries. 
The key trait of the Dutch multicultural model would involve the tendency to institutionalise cultural pluralism in the belief that cultural emancipation of immigrant minorities is the key to their integration into the Dutch multicultural society. This view is often rooted in the peculiar Dutch history of pillarisation, referring to the period from the 1920s to 1960s when most of Dutch society was structured according to specific religious (protestant, Catholic) or socio-cultural (socialist, liberal) pillars. It is in this period that Dutch society became used to emancipating national minorities, to tolerance regarding the sometimes deep differences between these minorities or 'pillars', and to the common Dutch practice of consensus building and negotiating between the pillars' elites (Lijphart 1976).

Historically positioning the 'Dutch Multicultural Model', it seems to refer primarily to policies that were developed in the 1980s and which are held to still be pertinent through so-called 'policy path-dependency.' In the 1980s, an 'Ethnic Minorities Policy' was developed that was targeted at specific cultural or ethnic minorities in Dutch society, such as migrant workers and post-colonial migrants from Surinam, the Moluccas Islands and the Dutch Antilles. Migrants were framed as 'minorities' in Dutch society instead of temporary guests, and the government decided to focus on those minorities whose position was characterised by an accumulation of cultural and socio-economic difficulties and for whom the Dutch government felt a special historical responsibility (Rath 2001). This framing of ethnic minorities reflected the framing of national minorities during the history of pillarisation. Although the Netherlands had been depillarising already since the 1960s, this suggests what Vink (2007) describes as a 'pillarisation reflex.'

This Ethnic Minorities Policy approximated what in the literature is described as a multiculturalist approach to migrant integration (Scholten 2011). It was firmly rooted not just in policy discourse, but also in academic discourse. In fact, this Ethnic Minorities Policy was produced and sustained by a relatively small but close and well-organised network of scholars and policymakers, described by Rath (2001) as a 'technocratic symbiosis'. On the one hand, this technocratic symbiosis was enabled by a culture of depoliticisation, or a 'gentlemen's agreement' not to turn migrant integration into a partisan issue, fearing radical parties that could play the race card. Also, there was a strong belief among policymakers in this period that integration as a social problem could be resolved if approached rationally, reflecting the broader belief in societal steering during that period. On the other hand, researchers played a leading role in policy formulation, via a governmentsponsored Advisory Committee on Minorities Research (ACOM) as well as a highly influential report from the Scientific Council for Government that provided the direct basis for the formulation of the Minorities Policy (Scholten 2011).

Together, researchers and policymakers in this period created a strongly centralised policy structure involving the co-optation of experts and ethnic elites (Guiraudon 1997). An important function of this technocratic symbiosis was to keep the debate on immigrant integration largely behind closed doors; it was structurally depoliticised. This created a specific sort of discourse as this technocratic symbiosis was held together by a so-called 'minorities logic': that is, a focus on what was specific to minorities in terms of culture and ethnicity rather than on their more 
general characteristics or what minorities had in common with other citizens. This illustrates how this discourse coalition not only sustained the discourse of that period, but also was itself held together by this discourse. There was a mutually reinforcing logic between the Minority Policy discourse and the discourse coalition by which it was sustained. At the same time, this symbiosis effectively excluded other discourses, such as the more critical-Marxist discourse that had emerged in the social sciences in the 1970s, anti-racism discourses (see Essed and Nimako 2006) as well as the nationalist (assimilationist) discourse, the latter having very little resonance in the field of politics in the 1980s.

The discourse of a Dutch multicultural model was thus clearly an outcome of coproduction of scholars and policymakers, within a specific historic setting. However, the idea of a Dutch multicultural model of integration also remains prominent in contemporary academic work. A study by Sniderman and Hagendoorn (2007), When Ways of Life Collide: Multiculturalism and its Discontents in the Netherlands, frames the Dutch approach in terms of the multiculturalist model. The authors claim that the labelling of ethnic identities has inadvertently deepened sociocultural cleavages in society instead of helping to bridge these differences. They take the Netherlands as their single exemplary case to establish their claims. They too root the Dutch approach back to the history of pillarisation: 'The Netherlands has always been a country of minorities thanks to the power of religion to divide as well as unite' (ibid.: 13). In addition, the 'collective trauma of World War II where the Dutch failed to resist the massive deportation of Jews would have contributed to that immigrant minorities have been seen in the perspective of the Holocaust $(\ldots)$ or that critical views of immigrants are labelled racist and xenophobic.' In the authors' view, due to these historical circumstances a multiculturalist model has taken root in the Netherlands.

Also among other Dutch scholars, thinking in terms of the Dutch multicultural model has acquired great resonance. Koopmans (2007) roots the Dutch approach to immigrant integration clearly in the history of pillarisation, which stressed ethnocultural cleavages. He claims that the application of this model to new immigrant groups has had strong adverse effects, as multiculturalism 'offers new ethnic and religious groups a formal and symbolic form of equality, which in practice reinforces ethnic cleavages and reproduces segregation on a distinctly unequal basis' (ibid: 5). Koopmans points in particular to 'path dependency' in terms of policy practices. Although formal policy discourse and public discourse seem to have changed, in their actual way of dealing with ethno-cultural diversity the Dutch have remained accommodative.

The abovementioned studies by Sniderman and Hagendoorn (2007) and Koopmans (2007) do not so much contribute to sustaining the Dutch multicultural model, but rather take it as a point of reference for explaining contemporary policy failure. Thus, if they use the term multicultural model, they do this in a normative, pejorative way. The label is used to disqualify certain policies that allegedly have been a failure. They 'blame the model.' Politicians as well as public intellectuals and some scholars retrospectively label the past as a time full of naive multicultural dreams, leading to a 'multicultural drama'. From 2003 onwards, well-known sociologists 
like Koopmans, Sniderman and Hagendoorn supported this perspective through their research, labelling Dutch policies as a multicultural model. This proved very influential in terms of the post-hoc labelling of Dutch policies, including those devised after the 1980s heyday of the Ethnic Minorities approach, in terms of a multicultural model.

Path-dependency is a key argument made in the context of this retrospective labelling of Dutch policies as multiculturalist, claiming that the 'multiculturalist' Ethnic Minorities Policy of the 1980s left institutional and discursive legacies that have continued to inform policy practices to the present day. For instance, Immigrant Language and Culture Instruction continued, although in different forms and with different wordings for its rationale, until after the turn of the Millennium. Whereas its goal was initially formulated as contributing to identity formation of migrants within Dutch society, its rationale was reframed in the 1990s in terms of 'languagetransition' by first mastering the mother-tongue language as support for the subsequent apprehension of Dutch as a second language. Another practice that was continued until well after the 1980s was the institutionalised practice of consultation with migrant organisations. At first, the establishment of migrant organisations and a National Consultative and Advisory Structure for Minorities had the objective of democratically involving migrants in policymaking processes. In the 1990s, the institutional involvement of migrant organisations was largely continued, although its advisory function was gradually marginalised. More recently, an important rationale for maintaining this form of institutionalised 'multiculturalism' is that migrant organisations provide channels for debate when incidents, such as the murder of the film-maker Van Gogh, trigger broad public and political controversy. Also in other fields, there are signs of path-dependency, such as in the existence of broadcast media for migrant groups and in the establishment of Islamic schools with state help.

\subsubsection{A Critical Assessment: Has There Ever Been a Dutch Multicultural Model?}

Social researchers thus played a key role in the construction of a 'multicultural model of integration', though in very different ways in different periods. Whereas at first they were key actors in the coproduction of this model within a technocratic symbiosis, later they contributed to the construction of a multicultural model more through their normative claims that the model was to blame for the 'multicultural tragedy'. Let us now take a more critical assessment of whether there is or ever has been a Dutch multicultural model, as well as the role that social scientists have played in critical reflection on discourses of migrant integration such as this multicultural model.

First of all, the claim that the development of Dutch policies is characterised by path-dependency ignores the sharp discontinuities in Dutch migrant integration policies over the past decades. The historical-institutionalist perspective on which 
the path-dependency argument is based connects Dutch migrant integration policies to the Dutch tradition of pluralism through 'pillarism', that is the institutionalisation of 'sovereignty within the own sphere' for each minority group. This connection between Dutch Ethnic Minorities Policies and the history of pillarisation must, however, be put in perspective. Dutch society was de-pillarising in many sectors already by the 1950s and 1960s, so well before the formulation of the Ethnic Minorities Policy. Pillarisation especially seems to have been powerful as a 'discourse'. The framing of migrants as minorities resonated with the framing of national minorities that the Dutch were already used to.

Others have added that it was not so much the Ethnic Minorities Policy per se that was inspired by pillarisation (Maussen 2009; Duyvendak and Scholten 2011). Rather, there was an influence from more generic institutions in Dutch society that were still to some extent pillarised, such as the Dutch tradition of state-sponsored special (religious) education, a pillarised broadcasting system and health system. Integration policy itself has never been oriented to the construction of minority groups as pillars. Furthermore, minority groups have never achieved the level of organisation (and separation) that national minorities achieved in the early twentieth century. In fact, we would emphasise that there never really was a 'national multicultural model', as slogans such as 'integration with preservation of cultural identity' were rejected already at this early stage. Only later would this slogan be applied, ex-post, to this period in public and academic discourse. Neither pillarisation nor multiculturalism was really embraced as a normative ideal. Instead, statements of multiculturalism referred in a more descriptive sense to the increase of diversity in society. As far as references to pillarisation or multiculturalism were used at all, these seem to have been much more pragmatic than normative. Our conclusion therefore is that 'multiculturalism' was actively co-produced by politicians and social scientists in order to disqualify policies of the past.

Besides the contested continuity between pillarisation and the alleged Dutch multicultural model, it is also obvious that this 'model' has not been very consistent since the 1980s. Already in the early 1990s, formal government policy changed in several important regards, when the Minorities Policy was reframed into the socalled Integration Policy that stressed socio-economic participation of immigrants as citizens over cultural emancipation of minorities. Promoting 'good' or 'active' citizenship became the primary policy goal, stimulating individual migrants to live up to their civic rights as well as their duties and to become economically independent participants in society. Whereas the Integration Policy had stressed 'active citizenship', the Integration Policy 'New Style' that was formulated in the early 2000s instead stressed 'common citizenship', which meant that 'the unity of society must be found in what members have in common $(\ldots)$ that is that people speak Dutch and that one abides to basic Dutch norms' (Treaties of Second House of Parliament, 2003-2004, 29203, nr. 1: 8.). Persisting socio-cultural differences were now considered a hindrance to immigrant integration. It was in this period, that the framing of the 'multicultural model' took place as a 'counter-discourse' against which new policy developments were to be juxtaposed. 
Even if we accept that the Netherlands has known a multicultural model in the 1980s, it still has to be proven that this model was also powerful in terms of concrete policy practices. There is much evidence that some policies that were initiated in the 1980s were continued until well after the Minorities Policy had been formally abandoned. However, the meaning and the use of these policies and the opportunities offered to migrants have radically shifted over time, also because the national and local levels of integration policy seem to have followed very different institutional logics. Whereas national policy discourse was inspired by politicisation, focusing events and a concern with grand themes like national identity and culture, local policy discourse seems to have been much more concerned with pragmatically dealing with problems, in a more instrumental policy logic.

An important instance of divergence in this respect concerns the recognition of ethno-cultural groups and minority organisations. In the early 1990s, national government formally adopted a more colour-blind citizenship approach, approaching migrants as citizens rather than as ethnic or cultural groups. This citizenship approach meant that various group-specific, tailor-made projects would have to be abolished. Yet, in practice, there has been a continued proliferation of such group-specific projects (De Zwart 2005). Often, there is a pragmatic need for policy practitioners to focus on specific groups and cooperate with migrant organisations, to be able to 'reach' the policy target groups and to acquire relevant knowledge and information about these groups (Poppelaars and Scholten 2008). Although these local practices often imply the de-facto recognition of cultural groups, it would be a mistake to consider them as actual multicultural policies. They are not inspired by an ideology of multiculturalism nor by a legacy of pillarisation, but rather by the more pragmatic need to recognise groups and develop tailor-made projects to conduct effective policies. As the mayor of the City of Amsterdam aptly phrases it, such practices are designed to 'keep things together.'

Thirdly, the role of social researchers has also evolved well beyond the 'technocratic symbiosis' that would have led to the coproduction of the Dutch multicultural model in the early 1980s. In fact, social research played a key role as well in 'punctuating' the structural equilibrium of the multicultural model. A new discourse coalition emerged at the end of the 1980s that advocated a more socioeconomic approach to immigrant integration to prevent migrants from becoming too dependent on welfare state provisions. This discourse coalition involved leading politicians (such as Prime Minister Ruud Lubbers, opposition leader Frits Bolkestein) as well as experts (such as Wim Albeda, chair of the Scientific Council for Government Policy and former minister of Social Affairs, and Han Entzinger). A new report from the Scientific Council for Government Policy (1989), clearly reflecting the ideas of this discourse coalition, played a key role in putting migrant integration back on the agenda in the late 1980s and gradually led to the introduction of the Integration Policy in the 1990s.

This episode brought an end to the strongly institutionalised research-policy nexus that had evolved in the 1970s and 1980s. ACOM was dissolved in 1992, and the use of social research in policymaking instead became more selective and more instrumental. Penninx (2005) describes what he calls policymakers' 'pick-and- 
choose strategies' to select only those strands of expertise that helped sustain the new policy discourse. The utilisation of research became more symbolic and dataoriented. Government wanted data to underline its new policy discourse rather than the more conceptual role played by research bodies such as ACOM and WRR. In this context, the government-associated Social and Cultural Planning Bureau (SCP) obtained a particularly prominent role in this field. Its regular 'Minorities Reports' were now often taken as anchor points for policy developments, especially as the SCP addressed a lot of attention to socio-economic areas and increasingly also areas of socio-cultural integration.

\section{4 'The French Assimilationist Model'}

\subsubsection{The Invention of the French Assimilationist Model}

Whereas the Dutch 'model' would be associated in the history of pillarisation, the French 'model' would be associated with images of the Revolution, the Third Republic's Hussards Noirs (the late nineteenth century nickname of teachers at the then newly established state-sponsored secularist schools), a universalistic understanding of citizenship, and an assimilationist perspective on immigrant integration. This cliché is a very pervasive one, in the French and international literature. However, the very notion of a 'republican model of citizenship' was considered as old-fashioned and outdated until the issue of immigrant integration was intensely politicised in the mid-1980s. Since then, the debate on republicanism has acted as a fig-leaf hiding the widely varied and contradictory framings of integration and citizenship issues resulting from public debates at the cross-roads of academic and political struggles to define the French perspective on citizenship.

Over the last three decades, there have been at least four different narratives used to describe the public problem of immigrant integration. Each of them was produced as both a public and a scholarly reasoning, valuing colour-blind and universal citizenship as a policy perspective and analytical framework for the integration of immigrants into contemporary France. More often than not, this dual aspect of the French model resulted from a dialogue between policymakers and scholars, in the form of ad hoc commissions (e.g. on French citizenship in 1987, and laïcité the very specific French conception of secularism, in public schools in 2004) or permanent institutions like the Haut Conseil à l'Intégration (High Council for Integration).

The first framing of the French model held sway in the mid-1980s following the abandonment of the myth that immigrants would return to their countries of origin: immigrants had become part of French society. At the same time, the Front National - an extreme right-wing party - began to impact public debate, achieving its first electoral successes in local (1983), European (1984) and national (1986) elections. The public issue of the integration of immigrant minorities was defined in terms of loyalty and allegiance, and soon thereafter in terms of religion (with the first veil affair in 1989). For the first time, scholars committed themselves to debates 
about how to deal with these issues. The construction of immigrant integration and Islam as a sensitive public issue paralleled its construction as a scholarly research field. In 1987, the Prime Minister launched a new commission in order to reassess the rules of access to French nationality. The so-called Long Commission (named after its president) involved scholars such as $\mathrm{H}$. Carrère d'Encausse, $\mathrm{P}$. Chaunu, E. Leroy Ladurie, D. Schnapper, A. Touraine. The outcome emphasised the importance of the French model of immigrant integration as a process of sociocultural assimilation and civic virtue, and the central role of nationality in access to citizenship. After several attempts, the new 1993 Law set new conditions for access to citizenship, requiring a 'manifestation de volonté' (an explicit voluntary request) and thereby eliminating the century-old tradition of automatic access to citizenship for those born in France (Weil 2002).

This nationality-based frame was replaced at the end of the 1990s by a new one focusing on anti-discrimination. The notion of civic virtue and socio-cultural integration became secondary to the definition of actual equality among French citizens, including those with a migrant origin (Conseil d'État 1997). The issue was of nationals needing to be provided with equal opportunities by French society and institutions - a notion that would easily fit with the programme described as 'multiculturalism' by many scholars.

Soon afterwards, the public framing of republican principles evolved towardss a third framing that precisely denounced the anti-discriminatory element as a "purely moral approach' unsuitable for confronting 'a stream of converging indices reflected in various forms of identity-related movements and tensions' (Haut Conseil à l'Intégration 2006: 17; authors' translation). In the early 2000s, the secular republic appeared as the new yardstick in the integration debate, making laïcité (the French public notion for secularism) the new core element of the definition of the French model. However, far from being defined in the terms of the 1905 Law (the founding law on laïcité), secularism became a moral framework that defined identity and was linked to new debates on gender equality, sexuality, and the 'deviance' of immigrant family structures (e.g.. accusations of polygamy and machismo or concerns about overcrowded households in immigrant neighbourhoods). The public response to this evolution is summed up in the Law of 15 March 2004, which disallowed 'ostensible religious signs' (read: Islamic headscarves) in public schools. This law was based on recommendations made by the 2003 Stasi Commission on laïcité, the composition of which resembled the Long commission on nationality of 1987. Leading scholars, including Jean Baubérot, Jacqueline Costa-Lascoux, Régis Debray, Gilles Kepel, Alain Touraine and Patrick Weil, figured among the 20 members of the commission. Its outcome made neutrality in the public sphere the main normative argument that drove this new definition of 'republican universalism'.

Eventually, a fourth framing of the French model appeared centre-stage after 2007, with a new focus on 'burqas' and a state-sponsored debate about national identity in 2009 and 2010. Debates about integration, and in particular the integration of Muslim groups, were no longer enclosed within the limits of abstract universalism. Different logics were at play in these discourses, including a new law banning fullface veiling (seen in certain instances as a failure of assimilation), the Law of 11 
October 2010, and the invention of the new juridical concept of 'immaterial public order' (Conseil d'État 2010). The new definition of the republic in this period turned to be grounded on a strong interplay between public order, national identity and citizenship. Not only was Islam highly culturalised in this accepted public definition of the French model, but republican identity was also transformed into a programme of strict cultural order.

\subsubsection{A Critical Assessment}

Let us turn back to the idea of a thick, stable, consistent and comprehensive French republican model. This cliché has been very pervasive in scholarship on the French case since the 1990s: most of the comparative social science literature on citizenship takes inspiration from it. What is missed in these analyses is a clear explanation of why and how the constant efforts to impose one standard definition of the idea of 'French republican citizenship' since the mid-1980s have produced highly culturalised conceptions that do not match the usual depictions of the French philosophy of integration and citizenship in colour-blind terms (see Bertossi 2012).

Whether the French model is defined as a discursive and institutional opportunity structure, a policy paradigm, a public philosophy or a cultural idiom, the literature views France as an un-multicultural country. It construes the French model as an institutional and ideological overarching order - a conception of 'institutional order' at odds with the existing literature on institutions. This national model is seen as all-encompassing, capable of organising the separation between public and private realms (through a strict colour-blind approach), the state and the church (laïcité), and foreigners and nationals (through an 'open' nationality regime).

As already mentioned, advocates of the path-dependent nature of models usually highlight the strong resilience of dominant political principles in each national context. Of course, they argue, deviations from- or challenges to- the core principles of a national model are always possible. According to Favell, for example, counterdiscourses or 'strange fruits' can develop from time to time, but 'normal politics' are mostly consistent with the model's principles (Favell 1998). Koopmans et al. (2005) also insist on possible changes in the configuration of citizenship, but they argue that national principles and core values are resistant to fundamental changes.

If this was accurate, however, the observation of official discourses on immigrant integration in France should show a constant effort by public actors to condemn unorthodox racial framings of citizenship, and to return to 'normal politics' and to the standard definition of the colour-blind and universalistic model. However, the analysis of 30 years of public narratives on immigrant integration shows something different, namely, that the production of a 'republican' definition of immigrant integration has paralleled an increased emphasis on ethnicity and race in French official discourses. This ethnic and racial framing cannot be understood merely as either a temporary 'strange fruit' or a marginal deviation from the norm: this is, as we shall see, how the French state has consistently been labelling its citizens over the past 30 years. 
This misconception of the French republican model has had consequences for the research agenda. Recent debates about republicanism among French scholars have highlighted the political power of the contradictions between the republican ideal of colour-blind equality, supposedly the foundation of French integration policies, and the actual discrimination suffered by immigrants and the stigmatisation they face in public and political debates as members of racial and ethnic groups (de Rudder et al. 2000; Fassin and Fassin 2006). One key topic of these debates has concerned the use of 'ethnic categories' to assess the level of racial and ethnic discrimination (Sabbagh and Peer 2008). The dilemma hinges on considering these categories either as a breach of the traditional colour-blind republican approach to citizenship (the French state does not formally recognise ethnic or racial groups), or, conversely, as an impediment to in-depth knowledge of the extent and nature of discrimination against French minority group members (discrimination that contradicts the principle of republican equality) (Martiniello and Simon 2005; Simon 2003).

This discussion of ethnic categories has not been limited to the question of the state's use of ethnic categories in the national census. It has focused on the legitimacy of their use by social scientists researching integration in France (Simon and Amiraux 2006). The issue of the use of ethnic categories in surveys and other social science research is a burning one in France, one which has nothing to do with the legitimate questions involved in scientific discourse and everything to do with the ideological nature of public debates.

This debate over the use of ethnic categories reveals two mutually exclusive conceptions of the French model. For those against using ethnic categories, the immense value of French republicanism is that it emancipates individuals through its specific universalistic programme, despite actual discrimination. By refusing any reference to ethnicity in research on integration and citizenship, many authors call for preserving this fundamental value (Schnapper 1994, 1999). They criticise fellow scholars for using ethnic and racial categories in their research, sometimes accusing them of 'creating' ethnic groups in France (Pierrot 1998: 235). Those in favour of adopting ethnic categories argue that the colour-blindness of the French model impedes the efforts to improve the status of ethnic and racial minority group members and reduce the discrimination they suffer, and that this model must be corrected in order to restore its initial value, upholding the motto of 'liberty, equality, fraternity' (Laborde 2010; Guérard de Latour 2010).

Regardless of the way in which French scholars approach the question of ethnic categories, they do share a similar conception of the value of republicanism: that is, republicanism is the model France has inherited from her political tradition, and compared to other models it represents the best ideological and policy framework to incorporate migrants and minority groups into French society. The existence of a singular French model remains undisputed. Scholars who criticise the contradictions and costs of republicanism nonetheless continue to accept or assume the existence of an imagined normative republic, characterised by abstract universalism, individual equality, and state neutrality in matters of religion. The French model, in other words, is at once a product of wishful thinking, a normative position and an analytical framework. 
Such debates do not only concern French academics or students. They have an impact of their own on the international literature, for various reasons: French scholars' work is read outside of France; French scholars are often the first interviewees that foreign (junior as well as senior) researchers meet in the first days of research in France; and French scholars are also involved in writing public or policy-oriented documents or articles in newspapers that often end up on the desks of international academics who analyse the French situation. This contributes to reinforcing the belief in the existence of the French model when it comes to migrants and minority groups.

\subsection{Conclusions: Coproduction, Integration Models and Their Performative Effect}

The examples of the Netherlands and France reveal the limits of the idea of unequivocally 'national' integration models. These examples also reposition the 'crisis of models' discourse beyond a before-and-after perception of a glorious past era that has given way to current decline. This repositioning allows us to be rid of the idea of normative blocks being put to the test in the early twenty-first century by multicultural and Muslim claims-making or reactionary nationalism.

Having said this, the question remains about the extent to which national models provide either a partial or a complete explanation of reality as it is empirically observed by field researchers. What can national integration models teach us about the practices of those who speak about the French Republic and Dutch multiculturalism? It is not enough to show, as we have done, the problems with concepts such as national models of integration. The fact that these models are not institutionally consistent, normatively coherent, evenly distributed and defined by agreed-on meanings does not mean that they are simply figments of the imagination of researchers who are engaged in ideological debates on the integration of immigrants.

It is not enough to conclude that national models do not exist because the reality that scholars observe is in fact saturated with 'modelised' thoughts and 'modelising' practices. The subjects of our research (social actors) believe in the existence of a French model built on principles inherited from the French Revolution or in the existence of a Dutch multiculturalism linked to the pillarisation legacy. It is therefore wrong to say that national models of integration should not be taken seriously because there are many people who take these models very seriously. Model concepts are used, imagined, negotiated, affirmed, contested, and challenged by different types of individual and collective actors in very different settings in working-class pubs, hospital hallways, in queues at social security offices, in police stations, school staff rooms, the reader commentary sections of newspaper websites, and EU summits of Interior Ministers, to name just a few (Bertossi 2011). A cognitive perspective helps avoid the positivist approach that often reduces questions about national models to questions about how actors are configured in 
idealistic structures and shaped by national cultural idioms or public philosophies. Models are not an a priori resource for action or an ex ante normative frame through which actors give shape to their strategies. Instead, these strategies give shape to varying, polysemic, and contradictory models. In other words, Dutch multiculturalism, French republicanism or other national stylised conceptions of citizenship cannot be held up as objective entities. For this reason and others we have already mentioned, they cannot be turned into the explanatory framework for the differences that exist among national contexts.

Our aim in this chapter has not been to propose a new theory of the notion of national integration models. Instead, we have argued that models of integration are an inappropriate tool for the comparative study of integration inasmuch as the objective of such research is to assess the success or failure of a national approach to integrating migrants and minority groups. We have shown that the notion of national models is tainted by normative (if not moral) connotations that hinder the ability of social scientists to address empirical reality.

If models tend to be taken as a substitute for reality and distort research strategies, we should not discard them entirely. A considerable amount of energy has been spent trying to extract a complex social reality from national integration models, with the risk of caricaturing the world that we study by using extremely attractive, but limited, narratives. It seems that it is time for us to move backwards, so to speak, inducing models from reality and conceiving of them as fluctuating dependent variables that must be explained. If we really want to understand the injustices of our societies, we believe that we need to study the actors who develop a multiplicity of conceptions of equality, inclusion, and identity, and examine from a sociological perspective how national models of integration play a role in these developments.

Open Access This chapter is distributed under the terms of the Creative Commons Attribution Noncommercial License, which permits any noncommercial use, distribution, and reproduction in any medium, provided the original author(s) and source are credited.

\section{References}

Bertossi, C. (2011). National models of integration in Europe: A comparative and critical analysis. American Behavioral Scientist, 55(12), 1561-1580.

Bertossi, C. (2012). The performativity of colour blindness: Race politics and immigrant integration in France, 1980-2012. Patterns of Prejudice, 46(5), 427-444.

Bertossi, C., \& Duyvendak, J. W. (2012). National models of integration: The costs for comparative research. Comparative European Politics, 10(5), 237-247.

Bommes, M., \& Morawska, E. (2005). International migration research. Constructions, omissions and the promises of interdisciplinarity. Aldershot: Ashgate.

Bommes, M., \& Thränhardt, D. (Eds.). (2010). National paradigms of migration research. Osnabruck: V \& R Unipress.

Bowen, J. (2007). A view from France on the internal complexity of national models. Journal of Ethnic and Migration Studies, 33(6), 1003-1016.

Brubaker, R. (1992). Citizenship and nationhood in France and Germany. Cambridge: Harvard University Press. 
Conseil d'État. (1997). Sur le principe d'égalité. Paris: La documentation française.

Conseil d'État. (2010). Study of possible legal grounds for banning the full Veil. Report adopted by the Plenary General Assembly of the Conseil d'État Thursday 25 March 2010. Paris: Conseil d'État/Reports and Studies Section.

De Rudder, V., Poiret, C., \& Vourc'h, F. (2000). L'inégalité raciste: l'universalité républicaine à l'épreuve. Paris: PUF.

De Zwart, F. (2005). The dilemma of recognition: Administrative categories and cultural diversity. Theory and Society, 34(2), 137-196.

Duyvendak, J. W., \& Scholten, P. W. A. (2011). Beyond national models of integration. The coproduction of integration policy frames in the Netherlands. Journal of International Migration and Integration, 12, 331-348.

Essed, P., \& Nimako, K. (2006). Designs and (Co)Incidents. Cultures of scholarship and public policy on immigrants/minorities in the Netherlands. International Journal of Comparative Sociology, 47(3/4), 281-312.

Fassin, E. (1999). 'Good to Think': The American reference in French discourses on immigration and ethnicity. In C. Joppke \& S. Lukes (Eds.), Multicultural questions. Oxford: Oxford University Press.

Fassin, D., \& Fassin, E. (Eds.). (2006). De la question sociale à la question raciale: représenter la société française. Paris: La découverte.

Favell, A. (1998). Philosophies of integration. Immigration and the idea of citizenship in France and Britain. Houndmills: Palgrave.

Favell, A. (2003). Integration nations: The nation-state and research on immigrants in Western Europe. Comparative Social Research, 22, 13-42.

Guérard de Latour, S. (2010). Vers la République des différences. Toulouse: Presses universitaires du Mirail.

Guiraudon, V. (1997). Policy change behind gilded doors: Explaining the evolution of Aliens' rights in France, Germany and the Netherlands, 1974-94. New Haven: Harvard University Press.

Hajer, M. (1995). The politics of environmental discourse: Ecological modernisation and the policy process. Oxford: Oxford University Press.

Haut Conseil à l'Intégration. (2006). Le bilan de la politique d'intégration: 2002-2005. Rapport au Premier ministre. Paris: La documentation française.

Ireland, P. R. (1994). The policy challenge of ethnic diversity: Immigrant politics in France and Switzerland (pp. 62-70). Cambridge, MA: Harvard University Press.

Joppke, C. (1999). Immigration and the nation-state: The United States, Germany, and Great Britain. Oxford/New York: Oxford University Press.

Koopmans, R. (2007). Good intentions sometimes make bad policy: A comparison of Dutch and German integration policies. In Friedrich Ebert Stiftung (Ed.), Migration, multiculturalism, and civil society (pp. 163-168). Berlin: Friedrich Ebert Stiftung.

Koopmans, R., \& Statham, S. (2000). Migration and ethnic relations as a field of political contention: An opportunity structure approach. In R. Koopmans \& S. Statham (Eds.), Challenging immigration and ethnic relations politics. Oxford: Oxford University Press.

Koopmans, R., Statham, P., Giugni, M., \& Passy, F. (2005). Contested citizenship: Political contention over migration and ethnic relations in Western Europe. Minneapolis: University of Minnesota Press.

Lijphart, A. (1976). The politics of accommodation: Pluralism and democracy in The Netherlands. Berkeley: University of California Press.

Laborde, C. (2010). Français, encore un effort si vous voulez être républicains! Paris: Seuil.

Martiniello, M., \& Simon, P. (2005). Les enjeux de la catégorisation. Rapports de domination et luttes autour de la représentation dans les sociétés post-migratoires. Revue Européenne des Migrations Internationales, 21(2), 7-17.

Maussen, M. (2009). Constructing Mosques. The governance of Islam in France and the Netherlands. PhD Thesis, University of Amsterdam. 
Penninx, R. (2005). Bridges between research and policy? The case of post-war immigration and integration policies in the Netherlands. International Journal on Multicultural Studies, 7(1), 33-48.

Pierrot, A. (1998). Le multiculturalism. In G. Ferréol (Ed.), Intégration, lien social et citoyenneté (pp. 234-251). Villeneuve d'Asq: Presses universitaires du septentrion.

Poppelaars, C., \& Scholten, P. W. A. (2008). Two worlds apart. The divergence of national and local integration policies in the Netherlands'. Administration and Society, 40, 4.

Rath, J. (2001). Research on immigrant ethnic minorities in the Netherlands. In P. Ratcliffe (Ed.), The politics of social science research. Race, ethnicity and social change (pp. 137-159). New York: Palgrave.

Rein, M., \& Schön, D. (1994). Frame reflection: Toward the resolution of intractable policy controversies. New York: Basic Books.

Sabbagh, D., \& Peer, S. (2008). The controversy over "statistiques ethniques". French Politics, Culture and Society, 26(1), 1-6.

Schain, M. A. (2009). The state strikes back: Immigration policy in the European Union. European Journal of International Law, 20(1), 93-109.

Schnapper, D. (1994). La communauté des citoyens: sur l'idée moderne de nation. Paris: Gallimard.

Schnapper, D. (1999). La relation à l'autre. Paris: Gallimard.

Scholten, P. W. A. (2009). The co-production of immigrant integration policy and research in the Netherlands: The case of the scientific council for government policy. Science and Public Policy, 36(7), 561-573.

Scholten, P. W. A. (2011). Framing immigrant integration: Dutch research-policy dialogues in comparative perspective. Amsterdam: Amsterdam University Press.

Simon, P. (2003). Challenging the French model of integration: Discrimination and the labor market case in France. Studi Emigrazione, 152, 717-745.

Simon, P., \& Amiraux, V. (2006). There are no minorities here: Cultures of scholarship and public debate on immigrants and integration in France. International Journal of Comparative Sociology, 47(3-4), 191-215.

Sniderman, P., \& Hagendoorn, L. (2007). When ways of life collide. Multiculturalism and its discontents in the Netherlands. Princeton: Princeton University Press.

Vertovec, S., \& Wessendorf, S. (Eds.). (2009). The multiculturalism backlash: European discourses, policies, and practices. London: Routledge.

Vink, M. (2007). Dutch multiculturalism: Beyond the pillarisation myth. Political Studies Review, $5,337-350$.

Weil, P. (2002). Qu'est-ce qu'un Français? Histoire de la nationalité française depuis la Révolution. Paris: Grasset. 